\title{
AN ETHNOBOTANICAL STUDY ON INDIGENOUS FOOD FLAVOURINGS AND AROMATIC ENHANCING PLANTS USED BY THE NATIVE COMMUNITIES OF THE CENTRAL REGION OF SARAWAK
}

\author{
NURUL AISYAH YUSLI ${ }^{1}$, NOORASMAH SAUPI ${ }^{*}$, SHIAMALA DEVI RAMAIYA ${ }^{1}$ \\ and YU ABIT LIRONG ${ }^{2}$ \\ ${ }^{1}$ Department of Crop Science, Faculty of Agricultural and Forestry Sciences, \\ Universiti Putra Malaysia Bintulu Sarawak Campus, 97008 Sarawak, Malaysia \\ ${ }^{2}$ Department of Animal Science and Fishery, Faculty of Agricultural and Forestry Sciences, \\ Universiti Putra Malaysia Bintulu Sarawak Campus, 97008 Sarawak, Malaysia \\ *E-mail: noorasmah@upm.edu.my
}

Accepted 4 October 2021, Published online 31 December 2021

\begin{abstract}
The uses of indigenous plants vary amongst native communities, from being consumed as vegetables, used as flavourings or added as an aromatic enhancer. However, records of their traditional use are sparse and most of the native knowledge on applications of these indigenous plants has not been passed down to later generations. The present study aims to record and identify communal knowledge from the Central Region of Sarawak with regards to the use of indigenous plants as food flavourings or aromatic enhancers. Face-to-face interviews with 150 respondents were conducted in a semi-structured manner to obtain the required information. A total of 27 plant species from 20 families were identified for their use by native people as food flavouring or aromatic enhancement. Zingiberaceae was found to be the most prevalent family of plants in this study with a representation of four species. Leaves were the part of the plants most commonly utilized by natives for flavouring purposes with 12 species being utilized in this manner. The mode of cooking varies within the community according to a preference for taste and aroma intensity as well as inherited oral knowledge passed down from older generations. This study recommends a full nutrient content analysis for the identified plant species shortly.
\end{abstract}

Key words: Food seasoning, fragrance crop, indigenous plants, native, Sarawak, traditional knowledge

\section{INTRODUCTION}

Over the centuries, plants have become an important resource to ensure the survival of humankind. Plants supply the bulk of oxygen in the atmosphere and serve a myriad of other beneficial uses to animals and humans. Plants are used as food, medicine, fibre, ornamentals, and also for numerous industrial purposes (Afolayan \& Jimoh, 2009). All parts of plants such as the leaves, stems, fruits, flowers, tubers, bark, seeds, and roots are utilized by different cultures across the globe for a wide and diverse range of applications (Mishra, 2015). Human societies have a history of utilizing readily available indigenous plants for a diverse range of purposes. Indigenous plants are plant species that occur naturally within a

* To whom correspondence should be addressed. given geographical area or were introduced to a particular region and evolved through human selection or natural processes (Phillips-Howard, 1999; van Rensburg et al., 2007). Indigenous plant species have contributed beneficially to local communities across the globe in economic, health and social terms (Keatinge et al., 2015). Indigenous plants have historically been exploited by different ethnic communities in Malaysia (Ainul Asyira et al., 2016). Voon and Kueh (1999) reported that Sarawak has a very rich tropical rainforest biodiversity that offers an excellent and readily available resource for rural communities. According to Ainul Asyira et al. (2016), rural communities show a preference to consume easily harvested indigenous plants growing wild in their vicinity. In Malaysia, indigenous plants are a daily source of nutrients, flavourings, therapy, and income (Det et al., 2013). In Borneo, the uses of 
indigenous plants such as Albertisia papuana Becc. was documented to be extensively used by the Dayak tribes of East Kalimantan (Sulvi et al., 2013; Purwayanti et al., 2013), West Kalimantan (Sulvi et al., 2013), and Central Kalimantan (Lusiana, 2009) as flavour enhancers due to their strong umami flavour. Getachew et al. (2019) also mentioned that indigenous flavouring agents are generally cheaper and safer than artificial flavourings. These findings highlighted the huge potential for indigenous plants as flavour and aroma enhancers. Flavour is a perceptual impression that is determined by the chemical sensation of the gustatory and olfactory systems (Wolfe et al., 2012). Schwab et al. (2008) and Barrett (2010) divided flavour into two aspects namely aroma and taste. In the human mouth, taste receptors sense the five taste modalities of sourness, sweetness, bitterness, saltiness and savoriness (Umami) (Trivedi \& Bijal, 2012; Witt, 2019). Flavour relies on taste whereas aroma depends on the concentrations of odour-active volatile compounds (Kader, 2008; Taylor \& Linforth, 2010).

Ethnobotany can be defined as studies related to the dynamic relationship between plants and people (Voeks, 2017). Ethnobotany investigates the use of plants in societies from various aspects ranging from environmental history, ecological economics and restoration, environmental ethics, and political ecology (Nolan \& Turner, 2011). Ethnobotany allows the opportunity to document oral knowledge from natives through the use of both quantitative and qualitative research instruments such as interviews and surveys. Oral knowledge and traditions are passed down through word of mouth from one generation to the next (Khodja et al., 2020). As such, oral traditions and knowledge need to be recorded and preserved to ensure that they are not lost over time.
Sarawak has an equatorial climate and is rich in tropical rainforests abundant with both animal and plant species (Trudy et al., 2012). There have been prior ethnobotanical studies in Sarawak but most have focussed on the use of indigenous plants for direct consumption (Voon \& Kueh, 1999; Shaffiq et al., 2013; Ainul Asyira et al., 2016; Saupi et al., 2020; Saupi et al., 2021). There is still a lack of research with regards to the traditional knowledge of plant usage as flavourings or aroma enhancers. Thus, the present study was conducted to investigate and document the use of indigenous plant species by native communities in Sarawak's Central region as food additives for flavouring and aroma enhancement.

\section{MATERIALS AND METHODS}

\section{Study site}

Sarawak is the largest state in Malaysia with an area of $124,450 \mathrm{~km}^{2}$. Sarawak lies between $0^{\circ} 50^{\prime}$ and $5^{\circ} \mathrm{N}$ latitude and $109^{\circ} 36^{\prime}$ and $115^{\circ} 40^{\prime} \mathrm{E}$ longitude, approximately north of the Equator. Sarawak's state boundaries extend $800 \mathrm{~km}$ along Borneo's northwest coast. It is located on the island of Borneo and is bordered by Sabah, Kalimantan, and Brunei. Sarawak is divided into three regions; Southern, Central, and Northern consisting of 12 divisions. This study was conducted in the Central region of Sarawak which comprises four divisions namely; Sibu, Bintulu, Kapit, and Mukah (Figure 1). The Central region of Sarawak covers an area of $66,376.11 \mathrm{~km}^{2}$ which is approximately $54 \%$ of the total land area of the state. The study was conducted around local farmers markets ("Tamu") and various native settlements.

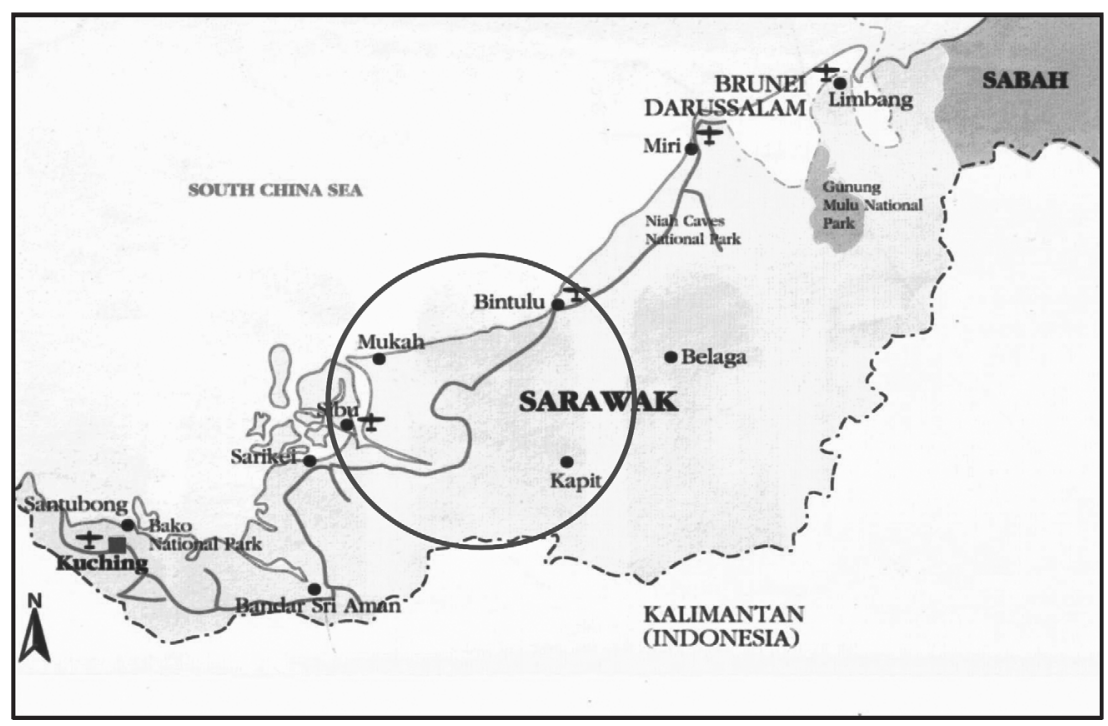

Fig. 1. Location of the study area. 


\section{Data collection}

Local farmers markets ("Tamu") and native settlement areas were selected as the main locations for conducting field surveys. 150 respondents participated in the present study. A Key Respondent Survey was carried out on each of the study respondents. Information was collected based on respondents' answers to the survey questionnaire. Questionnaires were written bilingually in English and Malay to aid with respondents understanding of the questions. Questionnaires consisted of three sections namely; personal information, basic information on the potential of plant species as food flavourings or aroma enhancers. Field surveys were conducted during the weekends for a period stretching between December 2020 to February 2021. Questionnaires were distributed in local market areas from 8 am to 12 noon during survey days. Weekends were selected due to the higher number of visitors in comparison to weekdays. In native settlement areas featured in this study, the questionnaire was distributed to any available residents within the vicinity. Each respondent was briefed before filling out the questionnaire. Sampling was carried out using a simple random sampling method to ensure an unbiased representation of the community. This method ensures an equal probability of any member of the statistical population to be chosen for the survey. Throughout each interview, a rapid appraisal method using semi-structured questionnaires was conducted to compile relevant and accurate information on plant samples. Demographically, respondents were aged between 15 to 75 years old. Questionnaires were answered according to the knowledge of the respondents. The interview section aimed to collect information from respondents on (i) local name, (ii) habitat, (iii) uses, (iv) plant parts used, (v) taste or aroma, (vi) method of consumption, and (vii) cooking methods. Illiterate respondents were assisted by the interviewers to fill in the survey forms. The local name of the plants, plant parts, and their applications was obtained from information collected in the survey forms. The first stage of species identification of the indigenous plants used was conducted immediately after the survey with assistance from the survey respondents via a transect survey and a brief interview session. Then, a thorough identification of plant species was conducted by identifying the morphology of the species based on the plant data bank and description based on Jansen (1993), Det et al. (2013), Ismail (2000) and Rukayah (2000).

\section{Data analysis}

The utilization of plants as food flavourings or aromatic enhancers was analysed using the Statistical Package for Social Science (SPSS), IBM ®V22.0
Software. Data were analysed descriptively to show frequency.

\section{RESULTS AND DISCUSSION}

\section{Demography of respondents}

Communities from the areas of Sibu, Kapit and Mukah participated in the survey. In terms of gender, $73.47 \%$ were female and $26.53 \%$ were male (Figure 2). There were approximately three times more female respondents than males. van Rensburg et al. (2007) surmised that women in Africa played a key role in the preservation of traditional knowledge. This may also be the case in Sarawak. Women tend to have more traditional knowledge of plants as they are mainly responsible for both the collection and cooking of the plants (Saupi et al., 2020). Mishra et al. (2015) explained that women are responsible for their household's diet which necessitates them to be informed on plant identification and uses. A total of $59.18 \%$ of respondents resided in suburban areas and $40.82 \%$ in rural areas (Figure 2). According to Cunningham (1994), those residing in more remote areas with easier access to natural resources usually have a higher awareness of traditional knowledge in comparison to those living in suburban and urban areas.

In terms of age, $46.94 \%$ of the respondents were aged from 31 to 59 years old, $42.86 \%$ of informants were above 60 years old and $10.20 \%$ of the study respondents were between 15 to 30 years old (Figure 2). Traditional knowledge is normally passed down from one generation to the next. The present study targeted respondents from the middle-aged to elderly demographic. Dixit and Goyal (2011) mentioned that elders are often viewed as a valuable national resource with adaptable and useful intergenerational oral information. In most cases, those belonging to the younger generation do not have adequate traditional knowledge. The younger generation tend to rely more on artificial sources and refuse to participate in practising traditional knowledge (Md. Sharif et al., 2013).

\section{Diversity of food flavouring and aromatic plants}

27 species of plants from 20 families were identified in the present study. Zingiberaceae had the highest number of taxa represented with four species. Zingiberaceae or commonly known as the ginger family is a family of pantropical herbs which are abundant in lowland tropical rainforests of the Malesian region; around 112 species can be found in Borneo (Mohamad \& Kalu, 2018; Mohamad et al., 2020). Natta et al. (2008) observed that Zingiberaceae was among the many useful plant species found in Southeast Asia. Plants in the Zingiberaceae family 


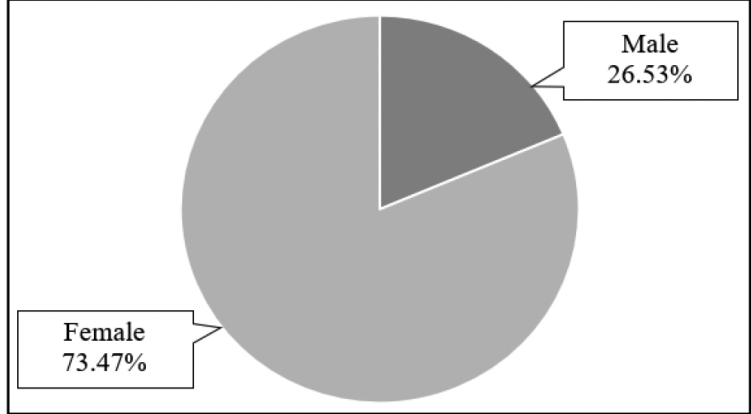

(a)

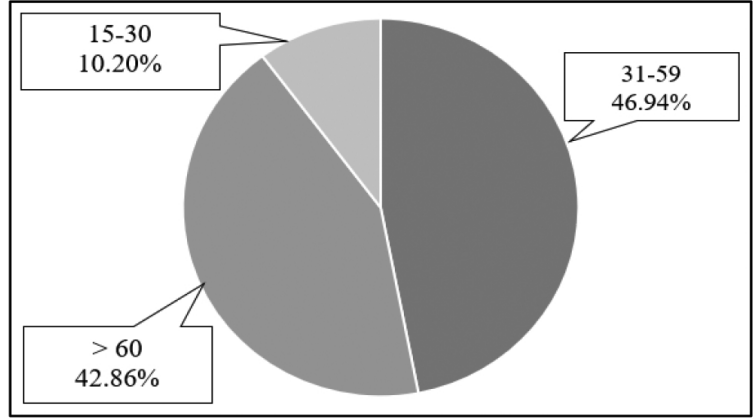

(c)

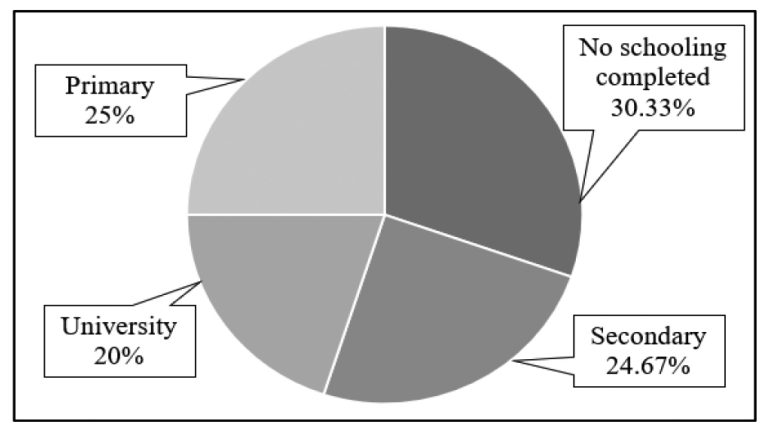

(e)

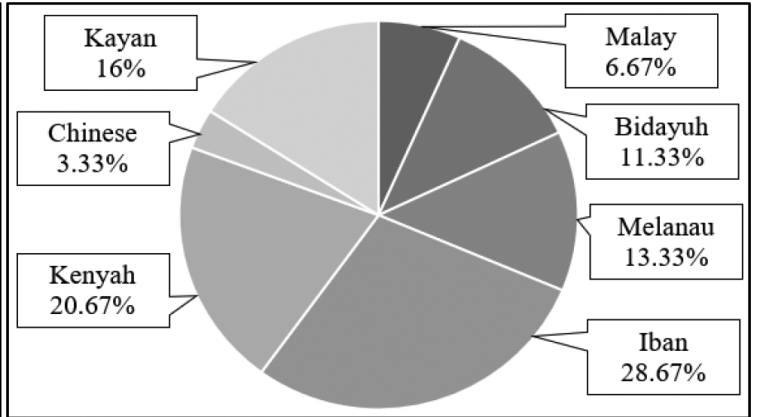

(b)

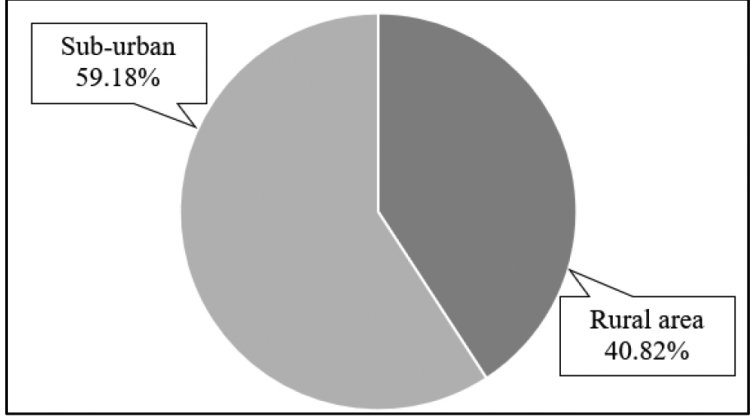

(d)

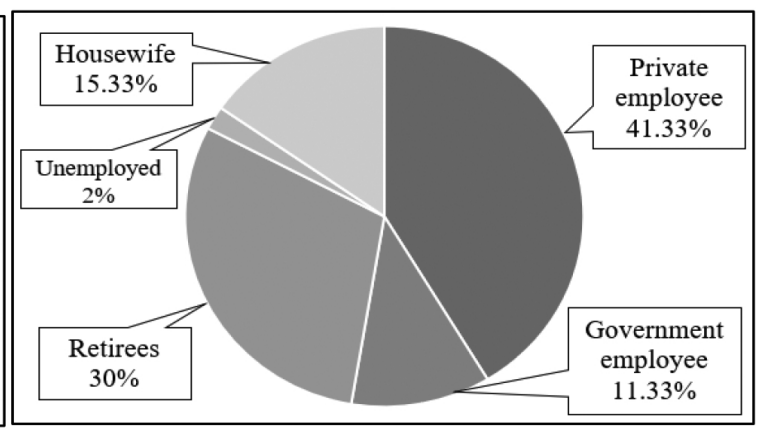

(f)

Fig. 2. Data set of respondents (a) gender of respondents; (b) ethnicity of respondents; (c) age of respondents; (d) living area of respondents; (e) education level of respondents; (f) occupation of respondents.

are known to possess antibacterial and antifungal properties, also species in this family are often used as food seasoning (Natta et al., 2008; Chua, 2008; Pintatum et al., 2020). The families of Clusiaceae, Menispermaceae, Poaceae, and Rutaceae had two representative species for each family. 15 other plant families identified were: Achariaceae, Amaryllidaceae, Arecaceae, Bromeliaceae, Cucurbitaceae, Dilleniaceae, Fabaceae, Lamiaceae, Marantaceae, Myrtaceae, Olacaceae, Pandanaceae, Piperaceae, Polygonaceae, and Solanaceae each represented by a single species.

The dominant part of the plant used for flavouring or aromatic effect was the leaves (Figure 3). Leaves of Allium tuberosum, Dillenia suffruticosa, Murraya koenigii, Pandanus odorus, Pangium edule, Persicaria odorata, Phacelophrynium maximum, Premna cordifolia, Pycnarrhena tumefacta, Scorodocarpus borneensis, Syzgium polyanthum, and Tiliacora traindra were found to be utilized by people of the Sarawak Central Region as flavourings or aromatic enhancer. This was followed by fruit ( 7 species $)$, plant stem (2 species), rhizome (2 species), flower (1 species), berry (1 species), seed (1 species), stalk (1 species), and pith (1 species). Aromatic and flavour compounds are biosynthesized in different plant parts such as the leaves, fruits, flowers, and roots (Schwab et al., 2008; Getachew et al., 2019). 


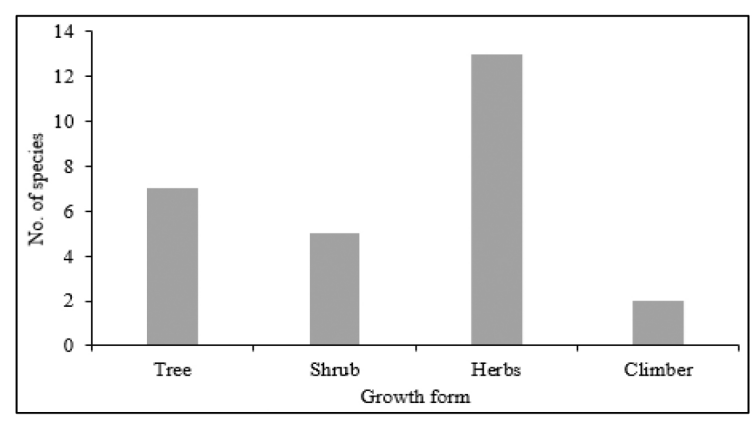

(a)

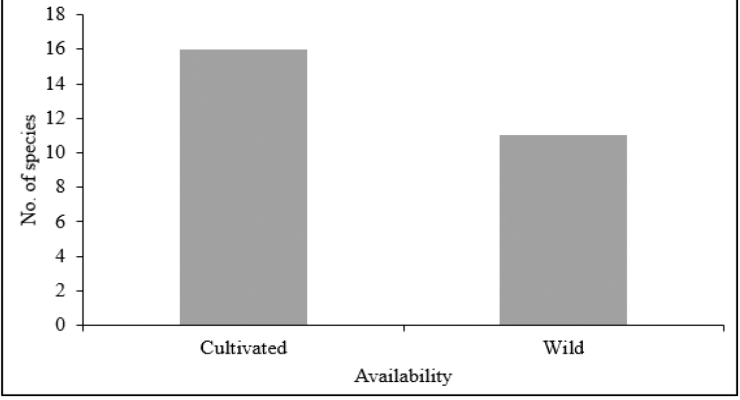

(b)

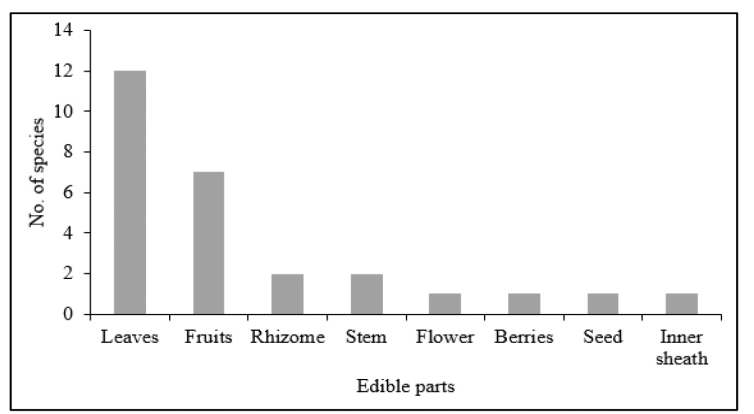

(c)

Fig. 3. Data set of plant diversity (a) growth form of the plants; (b) availability of the plants; (c) edible parts of the plants.

The plant species identified in the present study could be categorized into several forms such as trees, shrubs, palms, herbs, and climbers (Figure 3). Thirteen species identified in the present study were categorized into the herb forms; Alpinia galanga, Allium tuberosum, Ananas comosus, Cymbopogon citratus, Cymbopogon nardus, Eleiodoxa conferta, Etlingera coccinea, Etlingera elatior, Momordica charantia, Pandanus odorus, Persicaria odorata, Phacelophrynium maximum, and Zingiber officinale. Seven species were categorized into the tree form; Dillenia suffruticosa, Garcinia forbesii, Garcinia xanthochymus, Pangium edule, Parkia speciosa, Scorodocarpus borneensis, and Syzgium polyanthum. Five species were categorized as shrubs Citrus aurantifolia, Murraya koenigii, Premna cordifolia, Pycnarrhena tumefacta, and Solanum lasiocarpum. Only two species of plants identified in the present study were categorized into the climber form: Piper nigrum and Tiliacora triandra.

\section{Mode of consumption}

This investigation documented 11 species of plants used as flavourings and seasonings, 11 species used for aromatic or fragrance enhancement purposes, and five species that were used either for flavouring or aroma enhancing purposes (Table 2). The communities surveyed in this study utilized
G. forbesii and T. triandra by cooking them in fish soup to introduce a sour taste and offset the offflavours of freshwater fish. Pangium edule was added to the meats or other vegetables during the making of a local fermented dish called 'pekasam', due to its ability to eliminate rancid odours and prevent food spoilage (Figure 5). Pycnarrhena tumefacta, S. borneensis, and Syzgium polyanthum were used as food seasonings. Mohammed et al. (2019) reported that $P$. tumefacta possesses a savoury umami taste which is commonly used to enhance food by the Iban, Kenyah, Kayan, Bidayuh, and Kelabit ethnic groups in Sarawak. Scorodocarpus borneensis possesses a strong and pungent odour similar to garlic, leading to its use as a substitute for garlic by natives (Chai, 2000). Dillenia suffruticosa and $P$. maximum leaves are used to wrap glutinous rice traditional dish known as 'nubaq layaq'. Etlingera coccinea is commonly used as a marinade for fish, chicken, and pork in a local bamboo cooked dish called 'pansuh' (Figure 6).

\section{CONCLUSION}

Twenty-seven species of plants were identified for their use as flavouring and aroma enhancers by natives of the Sarawak Central Region. Each of the 


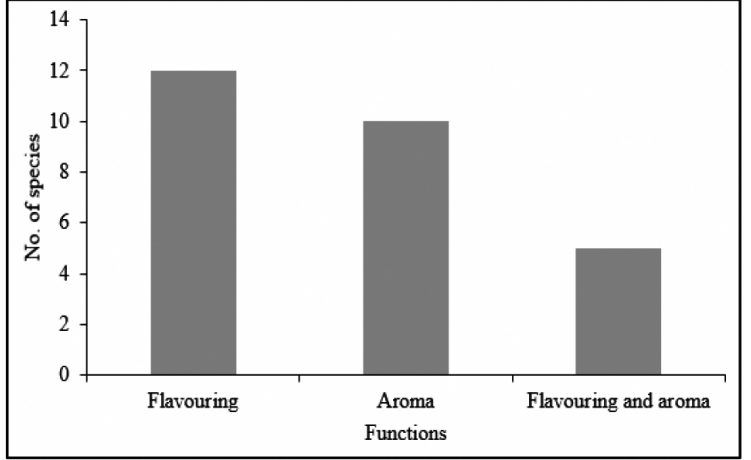

(a)

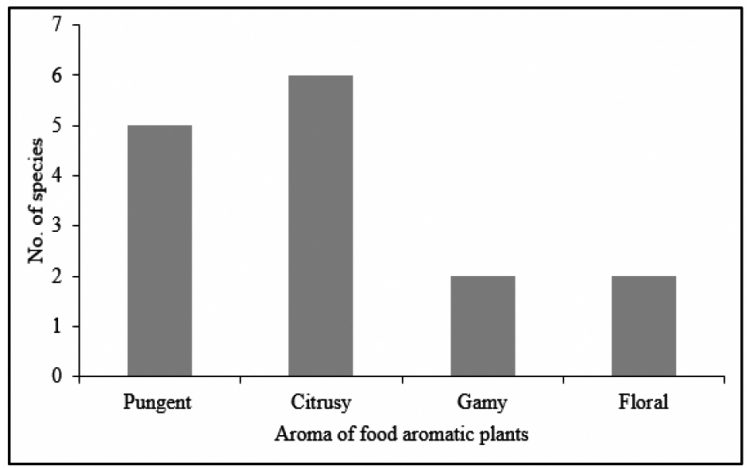

(c)

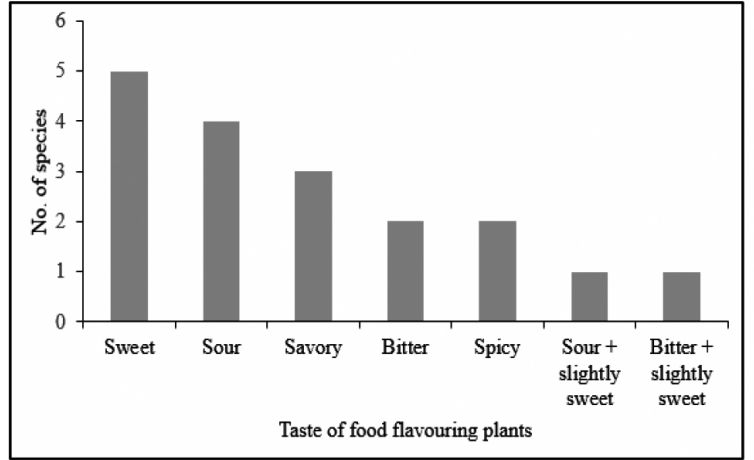

(b)

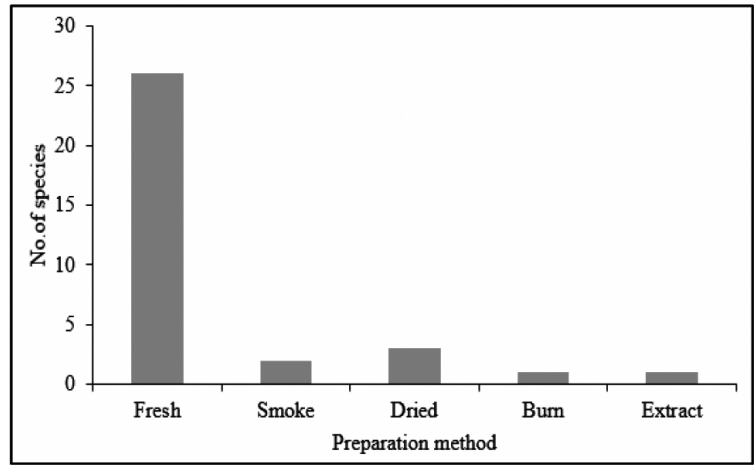

(d)

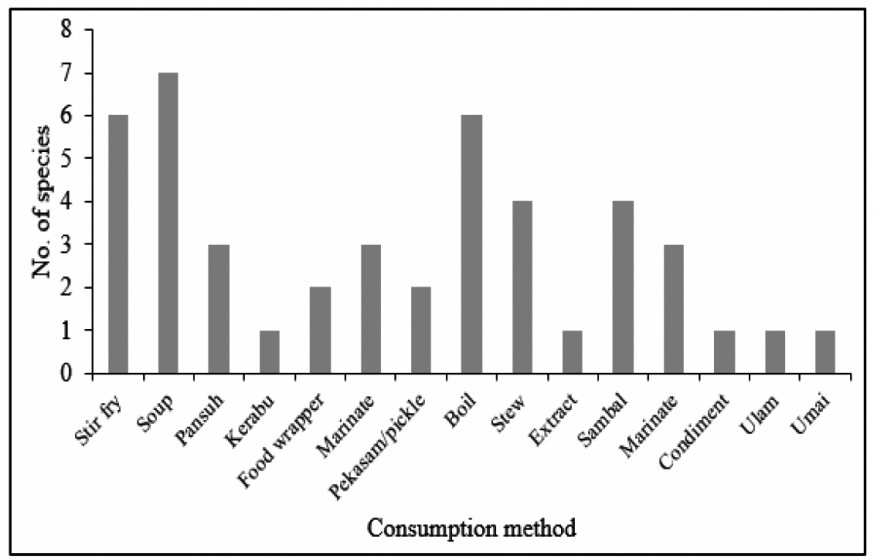

(e)

Fig. 4. Data set of plant consumption modes (a) functions of plants;(b) taste of food flavouring plants; (c) aroma of food aromatic plants; (d) preparation method; (e) consumption method.

species identified possessed unique characteristics to enhance dishes leading to various consumption methods. Leaves were the dominant part of the plant used for this purpose, followed by fruits, stem, rhizome, pith, berries, and flowers. Documentation of traditional knowledge on plants is essential to preserve this oral tradition for future generations. It is hoped that the present study will lead to further research into this subject matter, particularly in regards to the phytochemical aspects such as odouractive volatile compounds of the plants identified here. This research can be a strong motivator for the state to develop its natural products while introducing the many beneficial indigenous plants of Sarawak to the world. 
Table 1. The description of the plants used as food flavouring and aroma

\begin{tabular}{|c|c|c|c|c|c|}
\hline No. & Scientific name & Family & Local name & Plant parts & Availability \\
\hline 1. & $\begin{array}{l}\text { Allium tuberosum } \\
\text { Rottler ex Spreng. }\end{array}$ & Amaryllidaceae & Kucai & Leaves & Cultivated \\
\hline 2. & Alpinia galanga (L.) Willd. & Zingiberaceae & Lengkuas & Rhizome & Cultivated \\
\hline 3. & Ananas comosus (L.) Merr. & Bromeliaceae & Pineapple & Fruits (Flesh) & Cultivated \\
\hline 4. & $\begin{array}{l}\text { Citrus aurantifolia } \\
\text { (Christm.) Swingle }\end{array}$ & Rutaceae & Limau nipis & Fruits (Flesh) & Cultivated \\
\hline 5. & $\begin{array}{l}\text { Cymbopogon citratus } \\
\text { (DC.) Stapf. }\end{array}$ & Poaceae & Serai makan & Stem (Tiller) & Cultivated \\
\hline 6. & $\begin{array}{l}\text { Cymbopogon nardus (L.) } \\
\text { Rendle }\end{array}$ & Poaceae & Serai wangi & Stem (Tiller) & Cultivated \\
\hline 7. & $\begin{array}{l}\text { Dillenia suffruticosa } \\
\text { (Griff ex Hook.f. \& Thomson) } \\
\text { Martelli }\end{array}$ & Dilleniaceae & Buan & $\begin{array}{l}\text { Young and mature } \\
\text { leaves (Blade only) }\end{array}$ & Wild \\
\hline 8. & $\begin{array}{l}\text { Eleiodoxa conferta } \\
\text { (Griff.) Burret }\end{array}$ & Arecaceae & $\begin{array}{l}\text { Asam paya / asam } \\
\text { kelubi / maram }\end{array}$ & $\begin{array}{l}\text { Fruits } \\
\text { (Mesocarp) }\end{array}$ & Cultivated \\
\hline 9. & $\begin{array}{l}\text { Etlingera coccinea } \\
\text { (Blume) S. Sakai \& Nagam }\end{array}$ & Zingiberaceae & Tepus & Leaves (Pith) & Wild \\
\hline 10. & $\begin{array}{l}\text { Etlingera elatior } \\
\text { (Jack) R.M.Sm. }\end{array}$ & Zingiberaceae & Kantan/kechalak & Flower & Cultivated \\
\hline 11. & Garcinia forbesii King. & Clusiaceae & Kundung & Fruits (Pericarp) & Wild \\
\hline 12. & $\begin{array}{l}\text { Garcinia xanthochymus } \\
\text { Hook.f.ex. T. Anderson }\end{array}$ & Clusiaceae & Kandis & Fruits (Pericarp) & Wild \\
\hline 13. & Momordica charantia L. & Cucurbitaceae & Bitter gourd & Fruits (Pericarp) & Cultivated \\
\hline 14. & $\begin{array}{l}\text { Murraya koenigii (L.) } \\
\text { Sprengel }\end{array}$ & Rutaceae & Kari & $\begin{array}{l}\text { Young and mature leaves } \\
\text { (Blade with petiole) }\end{array}$ & Cultivated \\
\hline 15. & Pandanus odorus Ridl. & Pandanaceae & Pandan & $\begin{array}{l}\text { Young and mature leaves } \\
\text { (Blade only) }\end{array}$ & Cultivated \\
\hline 16. & Pangium edule Reinw. & Achariaceae & Kepayang & $\begin{array}{l}\text { Young leaves } \\
\text { (Blade with petiole) }\end{array}$ & Cultivated \\
\hline 17. & Parkia speciosa Hassk. & Fabaceae & Petai & Seeds & Wild \\
\hline 18. & $\begin{array}{l}\text { Persicaria odorata (Lour.) } \\
\text { Sojak }\end{array}$ & Polygonaceae & Kesum & $\begin{array}{l}\text { Young leaves } \\
\text { (Blade with petiole) }\end{array}$ & Cultivated \\
\hline 19. & $\begin{array}{l}\text { Phacelophrynium maximum } \\
\text { (Blume) K.Schum. }\end{array}$ & Marantaceae & Lung /isip/itip & $\begin{array}{l}\text { Young leaves } \\
\text { (Blade with petiole) }\end{array}$ & Wild \\
\hline 20. & Piper nigrum L. & Piperaceae & Lada & Berries & Cultivated \\
\hline 21. & Premna cordifolia Roxb. & Lamiaceae & Singkil / buas & $\begin{array}{l}\text { Young leaves } \\
\text { (Blade only) }\end{array}$ & Wild \\
\hline 22. & $\begin{array}{l}\text { Pycnarrhena tumefacta } \\
\text { Miers. }\end{array}$ & Menispermaceae & Tubu & $\begin{array}{l}\text { Young leaves } \\
\text { (Blade with petiole) }\end{array}$ & Wild \\
\hline 23. & $\begin{array}{l}\text { Scorodocarpus borneensis } \\
\text { Becc. }\end{array}$ & Olacaceae & Kesinduk & $\begin{array}{l}\text { Young leaves } \\
\text { (Blade only) }\end{array}$ & Wild \\
\hline 24. & $\begin{array}{l}\text { Solanum lasiocarpum } \\
\text { Dunal. }\end{array}$ & Solanaceae & $\begin{array}{l}\text { Terung Dayak / } \\
\text { terung asam }\end{array}$ & Fruits (Mesocarp) & Cultivated \\
\hline 25. & $\begin{array}{l}\text { Syzygium polyanthum } \\
\text { (Wight) Walp. }\end{array}$ & Myrtaceae & Bungkang & $\begin{array}{l}\text { Young leaves } \\
\text { (Blade with petiole) }\end{array}$ & Wild \\
\hline 26. & $\begin{array}{l}\text { Tiliacora triandra } \\
\text { (Colebr.) Diels }\end{array}$ & Menispermaceae & Kancam & $\begin{array}{l}\text { Young leaves } \\
\text { (Blade only) }\end{array}$ & Wild \\
\hline 27. & Zingiber officinale Roscoe. & Zingiberaceae & Halia & Rhizome & Cultivated \\
\hline
\end{tabular}


Table 2. Description of consumption method for the food flavouring and aroma enhancer plants

\begin{tabular}{lllll}
\hline No. Scientific name & Purpose & Taste/aroma & $\begin{array}{l}\text { Preparation } \\
\text { method }\end{array}$ & Consumption method \\
\hline 1. Allium tuberosum & Flavouring & Sweet & Fresh & $\begin{array}{l}\text { The leaves are chopped and stir-fried } \\
\text { with onion, garlic, and anchovies. }\end{array}$ \\
\hline 2. Alpinia galanga & Aroma & $\begin{array}{l}\text { Pungent } \\
\text { smell }\end{array}$ & Fresh & $\begin{array}{l}\text { The rhizomes are pound and mixed with } \\
\text { meats for 'pansuh' dishes, meat cooked } \\
\text { in bamboo along various spices. } \\
\text { Blend the rhizome with onion, } \\
\text { lemongrass, chillies, garlic, and cook } \\
\text { together with anchovies, shrimp paste, } \\
\text { and tamarind as 'sambal'. }\end{array}$ \\
\hline
\end{tabular}

\begin{tabular}{lllll}
\hline 3. Ananas comosus & Flavouring & $\begin{array}{l}\text { Sour with } \\
\text { slightly sweet }\end{array}$ & Fresh & $\begin{array}{l}\text { The juice is added to dishes to introduce } \\
\text { a sour taste. }\end{array}$ \\
\hline 4. Citrus aurantifolia & $\begin{array}{l}\text { Flavouring } \\
\text { and aroma }\end{array}$ & $\begin{array}{l}\text { Sour and } \\
\text { citrus smell }\end{array}$ & Fresh & $\begin{array}{l}\text { Juice is added to a local dish with onion, } \\
\text { chillies and raw fish called 'umai'. }\end{array}$ \\
\hline 5. Cymbopogon citratus & Aroma & Citrusy smell & Fresh & $\begin{array}{l}\text { The tillers are pounded and cooked } \\
\text { together with chicken, meat, or fish. }\end{array}$ \\
\hline 6. Cymbopogon nardus & Aroma & Citrusy smell & Fresh & $\begin{array}{l}\text { The tillers are pounded and cooked } \\
\text { together with chicken, meat, or fish. }\end{array}$ \\
\hline 7. Dillenia suffruticosa & Aroma & Gamy smell & Fresh & $\begin{array}{l}\text { The leaves are used to wrap the } \\
\text { glutinous rice. }\end{array}$ \\
\hline
\end{tabular}

\begin{tabular}{|c|c|c|c|c|}
\hline 8. Eleiodoxa conferta & Flavouring & Sour & Fresh & $\begin{array}{l}\text { The flesh is used for pickling and also } \\
\text { use as a substitute for tamarind. } \\
\text { The flesh is chopped and cooked with } \\
\text { chilli paste, anchovies, garlic, and } \\
\text { onion as 'sambal' }\end{array}$ \\
\hline
\end{tabular}

9. Etlingera coccinea Aroma Pungent smell Fresh $\begin{aligned} & \text { The pith is chopped and stir-fried } \\ & \text { together with chillies, onion, garlic, }\end{aligned}$
together with chillies, onion, garlic, and anchovies.

The pith is mixed together during the marination of meat for 'pansuh'.

\begin{tabular}{|c|c|c|c|c|c|}
\hline 10. & Etlingera elatior & Aroma & Pungent smell & Fresh & $\begin{array}{l}\text { The flower is chopped finely and } \\
\text { combined with lime, anchovies or fish, } \\
\text { onion, and chillies for the 'kerabu' dish. } \\
\text { The flower is cut in half and put into } \\
\text { the 'asam pedas' dish or 'pansuh'. } \\
\text { The flower is chopped finely and stir fry } \\
\text { with shrimp paste, onion, anchovies } \\
\text { and chillies. }\end{array}$ \\
\hline 11. & Garcinia forbesii & $\begin{array}{l}\text { Flavouring } \\
\text { and aroma }\end{array}$ & $\begin{array}{l}\text { Sour with the } \\
\text { citrusy smell }\end{array}$ & $\begin{array}{l}\text { Fresh or } \\
\text { smoked }\end{array}$ & $\begin{array}{l}\text { The rind was separated from the flesh } \\
\text { and was then smoked and cooked } \\
\text { together in fish soup. } \\
\text { Introduce sour taste in dishes. }\end{array}$ \\
\hline 12. & $\begin{array}{l}\text { Garcinia } \\
\text { xanthochymus }\end{array}$ & $\begin{array}{l}\text { Flavouring } \\
\text { and aroma }\end{array}$ & $\begin{array}{l}\text { The sour and } \\
\text { citrusy smell }\end{array}$ & $\begin{array}{l}\text { Fresh or } \\
\text { smoked }\end{array}$ & $\begin{array}{l}\text { The rind was separated from the flesh } \\
\text { and was then smoked and cooked } \\
\text { together in fish soup. } \\
\text { Introduce sour taste in dishes. }\end{array}$ \\
\hline 13. & Momordica charantia & Flavouring & Bitter & Fresh & $\begin{array}{l}\text { Stir-fried together with onion, garlic and } \\
\text { eggs. }\end{array}$ \\
\hline 14. & Murraya koenigii & $\begin{array}{l}\text { Flavouring } \\
\text { and aroma }\end{array}$ & $\begin{array}{l}\text { Savoury and } \\
\text { pungent smell }\end{array}$ & $\begin{array}{l}\text { Fresh or } \\
\text { dried }\end{array}$ & $\begin{array}{l}\text { The leaves are stewed together with } \\
\text { curry paste and coconut milk. }\end{array}$ \\
\hline 15. & Pandaus odorus & Aroma & Floral smell & $\begin{array}{l}\text { Fresh or } \\
\text { extract }\end{array}$ & $\begin{array}{l}\text { The leaves were washed, tied and } \\
\text { boiled for } 15 \text { minutes to get the extract } \\
\text { for making dessert. }\end{array}$ \\
\hline
\end{tabular}


Table 2 continued..

\begin{tabular}{llll}
\hline 16. Pangium edule Aroma & Bitter & $\begin{array}{l}\text { Fresh or } \\
\text { dried }\end{array}$ & $\begin{array}{l}\text { The young leaves were chopped and } \\
\text { fermented with fish or meat as } \\
\text { 'pekasam'. }\end{array}$ \\
\hline
\end{tabular}

17. Parkia speciosa $\quad$ Flavouring Bitter with $\quad$ Fresh
slightly sweet $\quad$ garlic and tamarind as 'sambal'. Stewed together with pounded cassava leaf, coconut milk, turmeric, and 'tempoyak'.

Eaten raw as 'ulam'.

\begin{tabular}{llll}
\hline 18. Persicaria odorata & $\begin{array}{l}\text { Flavouring } \\
\text { and aroma }\end{array}$ & $\begin{array}{l}\text { Savoury and } \\
\text { pungent smell }\end{array}$ & $\begin{array}{l}\text { Fresh } \\
\end{array}$
\end{tabular}

\begin{tabular}{|c|c|c|c|c|c|}
\hline 19. & $\begin{array}{l}\text { Phacelophyrynium } \\
\text { maximum }\end{array}$ & Aroma & Gamy smell & Fresh & $\begin{array}{l}\text { The leaves were used to wrap the } \\
\text { mashed rice called 'nubaq layaq'. }\end{array}$ \\
\hline 20. & Piper nigrum & Flavouring & Spicy & Dried & $\begin{array}{l}\text { The dried berries were crushed and } \\
\text { added inside the soup or any dishes } \\
\text { (black pepper). } \\
\text { The pericarp was removed. Dried } \\
\text { peppercorns were crushed and added } \\
\text { inside the soup or any dishes (white } \\
\text { pepper). }\end{array}$ \\
\hline
\end{tabular}

21. Premna cordifolia Flavouring Sweet $\quad$ Fresh
with bamboo shoots or anchovies. Leaves are chopped finely and cooked together with other ingredients as 'bubur pedas'

Stewed together with onion, garlic, anchovies and coconut milk.

\begin{tabular}{|c|c|c|c|c|c|}
\hline 22. & $\begin{array}{l}\text { Pycnarrhena } \\
\text { tumefacta }\end{array}$ & Flavouring & Savoury & Fresh & $\begin{array}{l}\text { The leaves are chopped finely and } \\
\text { cooked together inside the dishes. }\end{array}$ \\
\hline 23. & $\begin{array}{l}\text { Scorodocarpus } \\
\text { borneensis }\end{array}$ & Flavouring & Sweet & Fresh & $\begin{array}{l}\text { Stir-fried with onion, chillies, and garlic } \\
\text { for fish or chicken dishes also for soup } \\
\text { dishes. }\end{array}$ \\
\hline 24. & Solanum lasiocarpum & Flavouring & Sour & $\begin{array}{l}\text { Fresh } \\
\text { or burn }\end{array}$ & $\begin{array}{l}\text { The flesh was cut and boiled inside the } \\
\text { soup. } \\
\text { Burn the fruits, remove the burnt } \\
\text { exocarp, chop the fruit into small pieces } \\
\text { and mix with crushed chillies, and salt. } \\
\text { Stir-fry the flesh with shrimp paste, } \\
\text { onion, garlic, and smoked fish. }\end{array}$ \\
\hline 25. & Syzygium polyanthum & Flavouring & Savoury & Fresh & $\begin{array}{l}\text { Added into soup or 'pansuh' as } \\
\text { seasoning. }\end{array}$ \\
\hline 26. & Tiliacora triandra & Aroma & Pungent smell & Fresh & $\begin{array}{l}\text { The leaves were washed and added } \\
\text { to fish soup. } \\
\text { Mixed during marination of meat or fish } \\
\text { for 'pansuh'. }\end{array}$ \\
\hline 27. & Zingiber officinale & $\begin{array}{l}\text { Flavouring } \\
\text { and aroma }\end{array}$ & $\begin{array}{l}\text { The slightly } \\
\text { spicy and } \\
\text { citrusy smell }\end{array}$ & Fresh & $\begin{array}{l}\text { Cut or pound the rhizome and mix during } \\
\text { marination for 'pansuh'. } \\
\text { The rhizome is finely chopped and boiled } \\
\text { together in fish or chicken soup. }\end{array}$ \\
\hline
\end{tabular}




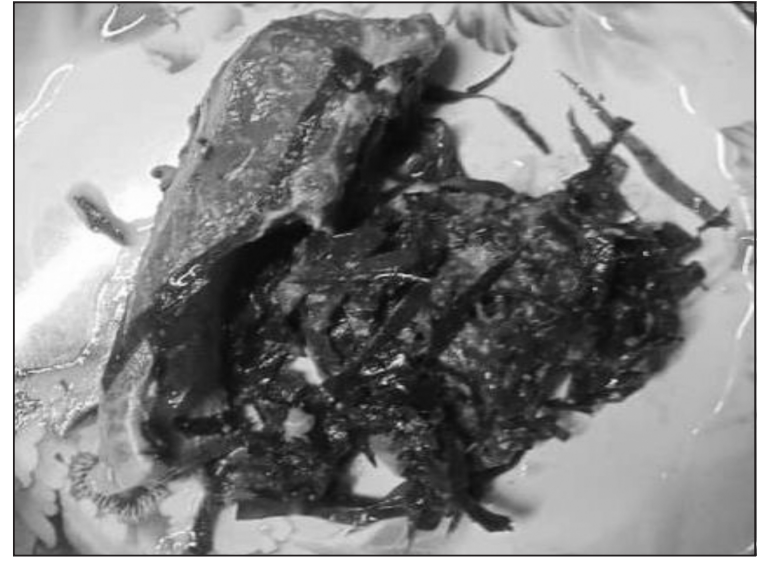

Fig. 5. Pangium edule in a local fermented food called 'pekasam'.

\section{REFERENCES}

Afolayan, A.J. \& Jimoh, F.O. 2009. Nutritional quality of some wild leafy vegetables in South Africa. International Journal of Food Sciences and Nutrition, 60(5): 424-431.

Ainul Asyira, S.A., Noorasmah, S., Sarbini, S.R. \& Muta Harah, Z. 2016. Mineral content of five indigenous leafy vegetables from Bintulu market, Sarawak Malaysia. Journal of Medicinal Herbs and Ethnomedicine, (2): 26-35.

Barrett, D.M., Beaulieu, J.C. \& Shewfelt, R. 2010. Color, flavour, texture, and nutritional quality of fresh-cut fruits and vegetables: Desirable levels, instrumental and sensory measurement, and the effect of processing. Critical Reviews in Food Science and Nutrition, 50: 369-389.

Cunningham, A.B. 1994. Combining skills: participatory approaches in biodiversity conservation in: Huntley, B.J. 1994. Botanical Diversity in Southern Africa. Proceedings of a Conference on the Conservation and Utilization of Southern African Botanical Diversity, Cape town, pp. 211.

Chai, P.P.K. \& Kho, S.Y. 2000. Development of Lanjak Entimau Wildlife Sanctuary as a Totally Protected Area: Kuching, in: Proceeding of ITTO Workshop 2000, Sarawak, pp.20.

Chua, S.K. 2008. Monitoring the quality of essential oil from Etlingera sp. (Zingiberaceae) by gas chromatography - mass spectrometry (GC-MS). Universiti Malaysia Pahang.

Det, P.A., Lau, C.Y., Umar, S., Brooke, P., Razili, R.M., Ismawi, H. \& Liew, S.M. 2013. Edible Wild Plants in Sarawak. Department of Agriculture Sarawak, Kuching.

Dixit, U. \& Goyal, V.C. 2011. Traditional knowledge from and for elderly. Indian Journal of Traditional Knowledge, 10(3): 429-438.

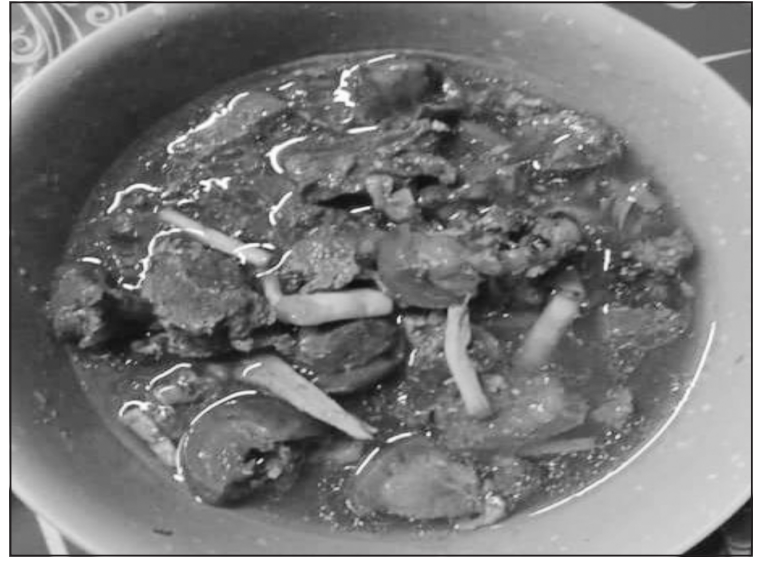

Fig. 6. Etlingera coccinea in a local dish called 'pansuh'.

Getachew, M., Awoke, S., Melaku, Y., Gashu, M. \& Gizachew, Z. 2019. Formulation of substantial natural flavors from plant materials for food and beverage industries. Journal of Food Processing and Technology, 10: 805.

Ismail, S. 2000. Sayuran Tradisional Ulam dan Penyedap Rasa. Penerbit Universiti Kebangsaan Malaysia, Bangi. 11-18 pp. (Malay).

Jansen, P.C.M., Lemmens, R.H.M.J. \& Oyen, L.P.A. 1993. Plant Resources of South-East Asia: Basic List of Species and Commodity Grouping. Pudoc, Wageningen. $372 \mathrm{pp}$.

Kader, A.A. 2008. Flavor quality of fruits and vegetables. Journal of Science of Food and Agriculture, 88(11): 1863-1868.

Keatinge, J.D., Wang, J.F., Dinssa, F. \& Ebert, A. 2015. Indigenous vegetable worldwide: Their importance and future development. Acta Horticulture, (1102): 1-20.

Khodja, N.K., Brahmi, F., Madani, K. \& Makhlouf, L. B. 2020. Ethnobotanical survey of three members of family Lamiaceae among the inhabitants of Bejaia, Northern Algeria. Journal of Complementary and Integrative Medicine, 17(4).

Lusiana, H. 2009. Isolasi dan uji anti plasmodium secara In Vitro senyawa alkaloid dari Albertisia papuana Becc. (MSc.). Institut Pertanian Bogor.

Mishra, S., Sharma, S. \& Vasudevan, P. 2015. Role of edible food plants in women's nutrition and health. In: Women, Technology and Development. P. Vasudevan (Eds.). Narosa Publishing House, New Delhi. pp. 1-17.

Md. Sharif, M.S., Mohd Zahari, M.S., Md Nor, N. \& Muhammad, R. 2013. Factors that restrict young generation to practice malay traditional festive foods. Procedia-Social and Behavioral Sciences, 101: 239-247. 
Mohamad, S. \& Kalu, M. 2018. Assessment of Zingiberaceae (Tribe Alpinieae) from North East Sarawak, Malaysia, in: International Conference on Biodiversity 2018, Malaysia. 269 pp.

Mohamad, S., Kalu, M. \& Poulsen, A.D. 2020. A new species and a new combination of Sundamomum (Zingiberaceae) from Sarawak, Borneo. Kew Bulletin, 75: 58.

Mohammed, N.K., Muhialdin, B.J., Masri, N.S., Sukor, R., Abd-El Aziem, F. \& Meor Hussin, A.S. 2020. Chemical compositions, antioxidant and antimicrobial activities of Tubu (Pycnarrhena longifolia) leaves used as ingredient in traditional functional foods. Food Research, 4(3): 823-830.

Natta, L., Orapin, K., Krittika, N. \& Pantip, B. 2008. Essential oil from five Zingiberaceae for antifood borne bacteria. International Food Research Journal, 15(3): 337-346.

Nolan, J.M. \& Turner, N.J. 2011. Ethnobotany: The study of people-plant relationships. In: Ethobiology. E.N. Anderson, D. Pearsall, E. Hunn, and N. Turner (Eds.). John Wiley \& Sons. pp. 135-147.

Phillip-Howard, K.D. 1999. The indigenization of exotic inputs by small-scale farmers on the Jos Plateau, Nigeria. In: Biological and Cultural Diversity: The Role of Indigenous Agricultural Experimentation in Development. G. Prain, S. Fujisaka and M.D. Warren (Eds.). Intermediate Technology Publications, London, United Kingdom. 80-91 pp.

Pintatum, A., Laphookhieo, S., Logie, E., Berghe, W.V. \& Maneerat, W. 2020. Chemical composition of essential oils from different parts of Zingiber kerii Craib and their antibacterial, antioxidant, tyrosinase inhibitory activities. Biomolecules, 10(2): 228.

Purwayanti, S., Gardjito, M., Santoso, U., Supriyadi \& Susanto, H. 2013. Determination of taste enhancing compounds from alkaline extraction of Bekkai Ian (Albertisia papuana Becc.) leaves by nanofiltration technique. Asian Journal of Food and Agro-Industry, 6(4): 171-179.

Rosli, N., Ismail, Z. \& Lepun, P. 2015. Plant used as natural dye by the Orang Ulu ethnics in Asap Koyan Belaga Sarawak, Malaysia. International Journal of Current Research, 7(8): 19770-19775.

Rukayah, A. 2000. Ulam dan Sayuran Tempatan Semenanjung Malaysia, Dewan Bahasa dan Pustaka, Kuala Lumpur. (Malay).

Saupi, N., Ainul Asyira, S., Muta Harah, Z., Sarbini, S.R. \& Yusli, N.A. 2020. An ethnobotanical study of indigenous leafy vegetables among local communities in Bintulu, Sarawak, Malaysia. Borneo Journal of Resource Science and Technology, 10(2): 155-165.
Saupi, N., Lepun, P., Alan, R., Muta Harah, Z., Ainul Asyira, S. \& Yusli, N.A. 2021. Morphological characterization and nutrient assessment of wild pepper, Piper umbellatum L. (Piperaceae) grown in Sarawak, Malaysia. Journal of Phytology, 13: 55-63.

Schwab, W., Davidovich-Rikanati, R. \& Lewinsohn, E. 2008. Biosynthesis of plant-derived flavor compounds. The Plant Journal, 54(4): 712-732.

Shaffiq, S.M., Sidik, B.J., MutaHarah, Z. \& Devi, R.S. 2013. Marketable wild fruits of Sarawak, Borneo: Their mode of consumption, uses and sugar profiles. Indian Journal of Traditional Knowledge, 12(2): 195-201.

Sulvi, P., Umar, S., Supriyadi \& Murdijati, G. 2013. Umami potential from crude extract of Bekkai Ian (Albertisia papuana Becc.) leaves, an indigenous plant in East Kalimantan-Indonesia. International Food Research Journal, 20(2): 545-549.

Taylor, A.J. \& Linforth, R.S.T. 2010. Food flavour technology. Flavour and Fragrance Journal, 25(6): 508.

Trivedi, B.P. 2012. Gustatory system: The finer points of taste. Nature, 486 (7403): S2-S3.

Trudy, R., Noelle, W., Paul, S. 2012. Asia and Oceania: International Dictionary of Historic Places. SEAP Publications, New York. 497 pp.

van Rensburg, W.J., van Averbeke, W., Slabbert, R., Faber, M., van Jaarsveld, P., van Heerden, I., Oelofse, A. 2007. African leafy vegetables in South Africa. Water SA, 33(3): 317-326.

Voeks, R. 2017. Ethnobotany. In: The International Encyclopedia of Geography: People, the Earth, Environment and Technology. D. Richardson, N. Castree, M.F. Goodchild, A. Kobayashi, W. Liu and R.A. Marston (Eds.). John Wiley \& Sons Inc. pp. 1-4.

Voon, B.H. \& Kueh, S.H. 1999. The nutritional value of indigenous fruits and vegetables in Sarawak. Asia Pacific Journal of Clinical Nutrition, 8(1): 24-31.

Witt, M. 2019. Anatomy and development of the human taste system. In: Handbook of Clinical Neurology (3rd series) Smell and Taste. R.L. Doty (Ed.). Elsevier B.V. pp. 147-171.

Wolfe, J.M., Kluender, K.R. \& Levi, D.M. 2012. Sensation \& Perception. Sinauer Associates, New York. 
